\title{
THE MEASURE OF DAMAGES FOR BREACH OF A CONTRACT CREATED BY ACTION IN RELIANCE
}

If $A$ makes a promise to $B$ and later fails to perform it, there are three possible consequences of a suit by $B$ against $A$. $B$ may take nothing by the promise; it may be fully enforced, specifically or in damages; or it maty be the basis for reparatory damages only. ${ }^{1}$ The measure of recovery will be the measure of $A$ 's legal duty to $B$ resulting from the promise. To create any duty at all, the law has required some further factor than the bare promise, and as there developed other bases for enforcing a promise than the quid pro quo of debt, the name consideration was attached to whatever other factors made it apparent that the promise ought to be enforced. ${ }^{2}$ The doctrine of consideration, as applied case by case, had no other consistency. Although consideration could be loosely described as a benefit to the promisor or a detriment to the promisee, it was not until Holmes that the theory of benefit or detriment as a mutual inducement for the promise became fully articulated. ${ }^{3}$ Substantially that definition was adopted by the American Law Institute. ${ }^{4}$ Yet Holmes also thought consideration to be as much a matter of form as the seal, ${ }^{5}$ betraying, perhaps, that his analysis imported a certain rigidity. ${ }^{6}$ If consideration was to be so narrowly defined, there had to be some provision in the Restatement for those cases which hold the promisor to his promise when there has been no conventional inducing return promise or performance. Section 90 of the Restatement says definite and substantial action in reliance on a promise, which the promisor should reasonably have foreseen, will make the promise binding, if injustice can only so be avoided. ${ }^{\text {? }}$

1. The term reparatory damages is intended to include both restitution and reliance damages.

2. See Anson, Contracts (Corbin's ed. 1924) 75 et scq., 120 ct seq., 121, 11. 1; Corbin, Cases on Contracts (2d ed. 1933) 196-214; Gr. Brit. Law Rev. Comm., Stxth Interim Report (1937) 12 et seq.; Holmes, The CoMmon Law (1881) 251 d seq.; 1 Williston, Contracts (Rev. ed. 1936) §99; Ames, The History of Assumpsit (1888) 2 HARV. L. REv. 1.

3. ". . . the promise and the consideration must purport to be the motive cach for the other in whole or at least in part. It is not enough that the promise induces the detriment or that the detriment induces the promise, if the other half is wanting.". Holmes, J., in Wisconsin \& M. Ry. v. Powers, 191 U. S. 379, 386 (1903). "It would cut up the doctrine of consideration by the roots if a promisee could make a gratuitous promise binding by subsequently acting in reliance on it." Holmes, $\mathrm{J}$., in Commonwealth v. Scituate Savings Bank, 137 Mass. 301, 302 (1884). Accord; McGovern v. New York, 234 N. Y. 377,138 N. E. 26 (1923) ; cf. Rice v. Almy, 32 Conn. 297, 304 (1864) and Justice Holmes in Marțin y. Meles, 179 Mass. 114, 60 N. E. 397 (1901).

4. "Restatement, Contracts (1932) \$75. Consideration must be "bargained for and given in exchange for the promise."

5 , See, Krell y. Codman, 154 Mass, 454, 456, 28 N. E. 578 (1891).

6. Compare Justice Holmes' search for a definite rule of law in torts. Baltimore \& O. R. R. v. Goodman, 275 U. S. 66 (1927).

7. Adoption of this doctrine is now being urged in England. GT. Bur. LAw REv. Comm., supra note 2 , at 24 . 
Considerable uncertainty is inherent in the Section, resulting from the attempt of the Restatement to unify an unusually diverse body of decisions by redefinition. Particularly perplexing is the further problem created by the Restatement's distinction between promises enforceable by reason of reliance and promises enforceable because consideration exists. That problem is whether the duty created by action in reliance should continue to be enforced up to the promisee's full expectation, or whether reliance damages alone shuuld be awarded. It has long been "ancient learning" that a promise supported by consideration thereby embodies a duty co-extensive with its terms, and that, conversely, a promise not so supported is midum pactum. ${ }^{8}$ It has therefore been urged that if mere action in reliance is to raise a duty in the promisor, the duty must be co-extensive not with the promise but rather with the action, as ex hypothesi there is no consideration, no contract, and the duty of the promisor can at most be only to restore the stafts quo. ${ }^{3}$ But as soon as the creation of a duty by a promise was recognized at all by the common law, that duty was extended to the limit of the promise-to the expectation interest. The duty of the promisor was later said to be bottomed upon consideration, and recently the idea of consideration has been refined to include only a bargained-for exchange. But assuming that a contract is "a promise . . . the performance of which the law in some way recognizes as a duty," 10 there is a considerable body of enforced promises that have not had consideration as so defined by Holmes. Consideration, instead of being essential to enforcement of the whole promise, may be but one of several grounds for enforcement. And for contracts in which consideration does not exist in its modern restricted form, there seems to be no reason why eniorcement should not be granted to the full extent to which promises were enforced when consideration was a broad and unanalyzed term-namely, to the full expectation interest of the promisee. An examination of the reliance cases may disclose whether they are the result of a faulty conception of what should make a promise enforceable, whether reliance damages alone should be given if damage is shown, or whether there are other well-established reasons for enforcing the full promise than a bargained-for exchange. ${ }^{11}$

8. ". . . . consideration is the universal requisite of contracts not under ssal," Anson, Contracts (Corbin's ed. 1924) 120; of. the 1930 edition at page 121 of seg. See 1 Winlrston, Contracts (Rev. ed. 1936) \$99; Corbin, Jr. Justice Cardazo asd the Law of Contracts (1939) 48 YALE L. J. 426, 430, 39 CoL L. REv. $56,60,52$ Hasi. L. Rev. 408, 412.

9. Shattuck, Gratuitons Promises-A New II'rit? (1937) 35 Mren. L. Ra: 903 ; Gardner, An Inquiry into the Principles of the Law of Contracts (1932) 46 H.ans. L. REv. 1, 22; cf. Fuller, The Reliance Intcrest in Contract Damages (1936-1937) 46 Y'sLE L. J. 52, 373, at 64-66, 69-71, 401-420. Confra: 1 Wrusstos, Costricts (Res. ed.

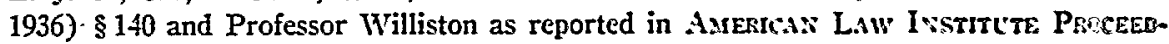
INGS; 'Vol: TV, Appendix (1926) 85-114.

10. Restateanent, Contracts (1932) $\$ 1$.

11. Probtems involving "past consideration" are omitted from this diceussion. 


\section{A. Promises to Make a Gift}

Usually held enforceable are promises to give money if the promisee will move and live next to the promisor, ${ }^{12}$ or remain sober and virttous, ${ }^{13}$ or refrain from smoking or drinking. ${ }^{14}$ In such cases the action of the promisee is usually bargained-for, and at least the form of the promise will support a finding that performance of the condition was the consideration. But in a promise to pay for a trip to Europe, ${ }^{15}$ or for education, ${ }^{16}$ a bargained-for exchange is more difficult to discover. Courts are apt to say the trip was taken at the promisor's request and is therefore sufficient "consideration". In fact neither the trip nor the expenditure made in pursuit of education readily fit conventional ideas of a bargained-for exchange. It is really the unfairness of leaving the promise unenforced after reliance, bargained-for or not, that prompts the result. So with a promise to pay for land, ${ }^{17}$ a house, ${ }^{18}$ a mill, ${ }^{10}$ or a warehouse, ${ }^{20}$ on the faith of which the promisee incurs the liability suggested. Promises to keep up the salaries of those going to war, ${ }^{21}$ or to give money that the promisee need not work have been similarly enforced. ${ }^{22}$ It is true the desire for the action of the promisee in these cases may very likely be the inducing cause for the promise, or its motive, but motive is not a criterion of consideration; and stating the promise as coupled with a request is generally a fiction. The bare promise is enforced because the promisee, as should be expected, has depended on it. As the reliance is co-extensive with the promise, the whole promise is of course enforced.

Marriage Settlements: The marriage settlement cases have caused some doctrinal difficulty because the only tangible detriment incurred in reliance

12. Adams v. Honness, 62 Barb. 326 (N. Y. 1872) ; if. Matter of Cole, 202 App. Div. 546, 195 N. Y. Supp. 541 (2d Dep't 1922).

13. Dunton v. Dunton, 18 Vict. L. R. 114 (1892) ; if. Werner v. Werner, 169 App. Div. 9, 154 N. Y. Supp. 570 (1st Dep't 1915).

14. Hamer v. Sidway, 124 N. Y. 538, 27 N. E. 256 (1891); Lindell v. Rokes, 60 Mo. 249 (1875) ; cf. Daykin v. Daykin, 1 Ohio L. Abs. 536 (1923).

15. Devecmon v. Shaw, 69 Md. 199, 14 Atl. 464 (1888).

16. Young v. Boyd, 107 Md. 449, 69 Atl. 33 (1908); Robinson v. Hayes' Estate, 207 App. Div. 718, 202 N. Y. Supp. 732 (3d Dep't 1924), aff'd, 239 N. Y. 512, 147 N. E. 175 (1924).

17. Berry v. Graddy, 58 Ky. 553 (1859). Accord: Homan v. Stcele, 18 Neb. 652, 26 N. IV. 472 (1886). But cf. In re Estate of Fisher, 128 Ore. 415, 274 Pac. 1098 (1929).

18. Crosbie v. M'Doual, 13 Ves. 148 (Ch. 1806) ; Herron v. Brinton, 188 Iowa 60, 175 N. W. 831 (1920) semble.

19. Steele v. Steele, 75 Md. 477, 23 Atl. 959 (1892).

20. Skidmore v. Bradford, L. R. 8 Eq. 134 (1869).

21. Davies v. Rhondda Dist. Urban Council, 87 L. J. K. B. (N.s.) 166 (C. A. 1917). Accord: Board of Commissioners v. Mertz, 27 Ind. 103 (1866) ; Board of Commissioners v. Wood, 39 Ind. 345 (1872); cf. State v. Lum, 95 Conn. 199, 111 Atl. 190 (1920); State ex rel. Hess v. City of Akron, 56 Ohio App. 28, 10 N. E. (2d) 1 (1936).

22. Ricketts v. Scothorn, 57 Neb. 51, 77 N. W. 365 (1898) ; De Paola v. Greenspan, 167 Misc. 467, 3 N. Y. S. (2d) 590 (Sup. Ct. 1938). 
on the settlement is the performance of the contract to marry, a pre-existing legal duty. But whether or not the explanation is that the performance of a pre-existing duty to a third person, here the fiancé(e), may be a consideration, ${ }^{23}$ courts have held the occurrence of the marriage a sufficient reason for enforcing the promise. ${ }^{2 t}$ In fact, the promisor may not have bargained for the marriage, which would negative conventional consideration. As for reliance, the promisee might have married without the promise, leaving as the reliance-detriment only the disappointment of an expectation held when the marriage took place. Although mere disappointment has not attained explicit recognition as a detriment, there is no consistent explanation of all these cases other than that expectation alone will, at least in this moral atmosphere, induce the courts to preserve the promisee's expectation and turn the promise into a contract. Here again there is no suggestion the duty should be limited to anything less than the terms of the promise, as there is no practical way to determine the monetary extent of the reliance.

Charitable Subscriptions: Although it has been urged they should be treated as sui generis, ${ }^{25}$ the charitable subscription cases are nonetheless abundant authority for the proposition that action induced by a promise is sufficient to make the promise enforceable. ${ }^{26}$ The subscription was at first enforced only if a request for the action could be implied so that the action could be thought of as bargained-for. ${ }^{27}$ Later the implication became increasingly artificial, leading to recognition that the request was unnecessary..$^{23}$ The objection

23. See De Cicco v. Schweizer, 221 N. Y. 431, 117 N. E. 807 (1917); 1 WuLusro:; Contracts (Rev. ed. 1936) $\S \S 131,103 D$; Corbin, Does a Pre-cxisting Duty Defcat Consideration? (1918) 27 YALE L. J. 362.

24. De Cícco v. Schweizer, 221 N. Y. 431, 117 N. E. 807 (1917); Plaslen v. Lnited States Trust Co., 186 N. Y. 178, 78 N. E. 943 (1905); Shadwell v. Shadivell, 9 C. B. N. S. 159 (1860). But cf. Ayliffe v. Mr. Justice Tracy, 2 P. W'ms. 65 (Ch. 1722). Cf. Nicholson v. Acme Cement Plaster Co., 145 M1o. App. 523, 122 S. IV. 773 (1909).

25. Billig, The Problem of Consideration in Charitable Subseriptions (1927) 12 CoRN. L. Q. 467 ; Shattuck, supra note 9, at 931.

26. See 1 Williston, Contracts (Rev. ed. 1936) $\$ 116$ and cases cited; Billig, supra note 25, at 469-473; Note (1925) 38 A. L. R. 868 ef seq. England refuses enforcement In re Hudson, 54 L. J. 811 (Ch. 1885). But it is urged the policy be changed by legislation. Gr. Brit. LAw Rev. Coarar., supra note 2, at 16.

27. Trustees of Bridgewater Academy v. Gilbert, 19 IIass. 579 (1824); Trustees of Hamilton College v. Stewart, 1 N. Y. 581 (1848); Barnes v. Perine, 12 N. Y. 18 (1854) ; cf. Amherst Academy v. Cowls, 23 Mfass. 427 (1828). New Yorl: seems to have clung most tenaciously to the implication. Keuka College v. Ray, 167 N. Y. 95, 60 N. E. 325 (1901); Allegheny College v. Nat. Bank, 246 N. Y. 369,159 N. E. 173 (1927). But there are intimations that if it is impossible to imply a request, reliance will suffice. I \& I Holding Corp. v. Gainsburg, 276 N. Y. 427, 12 N. E. (2d) 532 (1938).

28. Beatty v. Western College, 177 Ill. 280,52 N. E. 432 (1898); cf. In re Estate of Griswold, 113 Neb. 256, 202 N. W. 609 (1925). Compare the unreality of the implication of a request in the modern cases [School Dist. v. Sheidley, 138 Mo. 672, $40 \mathrm{~S}$. W. 656 (1897) ; Y. M. C. A. v. Estill, 140 Ga. 291, 78 S. E. 1075 (1913)] with the impliation in the old cases where, with small communities, it had a basis in fact. Trusters $v$. Allen, 14 Mass. 172 (1817); George v. Harris, 4 N. H. 533 (1829); Fremont Ferry and 
is made, however, that courts do not require proof of actual detriment, and that although there have been cases denying enforcement when no teliturce was proved, ${ }^{29}$ there have also been intimations that no "consideration" is necessary for a promise to charity. ${ }^{30}$ And the variety of reasoning applied does in fact show a strong tendency to enforce such promises por se.

Yet assuming that reliance upon a promise is sufficient to raise a duty in the promisor, a substantial number of the cases support the assumption in theory, some on their facts apart from the legal rationale of the case. Where reliance is not shown, moreover, it may fairly be presumed in view of the purpose for which the subscription was obtained. If that be deemed unwarranted, and the cases granting recovery where no reliance is shown are taken with those intimating none is necessary, they are at least $s u b$ rosa authority for the proposition that a sufficiently evidenced expectation which the court thinks reasonable and strong enough will be sufficient without more to raise a duty in the promisor not to disappoint it. Courts are of course impelled by the fact that the promisee is an institution which must proceed at least in part upon the theory such expectation interests will be protected. This ansy enforcement of charitable subscriptions is further dependent upon the idea that social policy favors it, and as they are usually sued upon only after the death of the promisor, there is little said to the contrary. It is questionable whether such a result would persist in the face of a reversal of policy, ${ }^{31}$ or a showing that the enforcement would work hardship upon the promisor or his dependents. Then one would expect definite and substantial action in reliance to be required. But even then the promise must be enforced to its full amount or not at all, in view of the difficulty of apportioning any definite action to any specific promise.

Gifts of Land: If possession has been taken and substantial improvements made, equity will specifically enforce a parol contract for the sale of land which would otherwise be unenforceable under the Statute of Frauds. ${ }^{32}$ The theory is that possession and improvements are part performance which either

Bridge Co. v. Fuhrman, 8 Neb. 99 (1879). Compare the business subscriptions. Homan v. Steele, 18 Neb. 652,26 N. W. 472 (1886); Sherwin v. Fletcher, 168 Mass. 413, 47 N. E. 197 (1897) ; Martin v. Meles, 179 Mass. 114, 60 N. E. 397 (1901).

Other fictitious bases for enforcing charitable subscriptions are discussed in $1 W^{\prime} 11$ L1sTON, Contracts (Rev. ed. 1936) §116; Billig, loc. cit. supra note 25; Shattuck, supra note 9, at 931 et seq.

29. Shattuck, supra note 9 , at 932, n. 76 .

30. In re Estate of Griswold, 113 Neb. 256, 202 N. W. 609 (1925); Billig, supro note 25 , at 483 , n. 51 ; Note (1925) 138 A. L. R. 868, 873.

31. See Reimensnyder v. Gans, 110 Pa. St. 17, 20, 2 Atl. 425,428 (1885) rc a statute rendering a charitable subscription without a fair consideration void if the donor died within one month from its date: ". . . the statute is a wholesome one, designed to protect the dying from the craft of priest and layman alike, when they come not to minister comfort and spiritual consolation, but to gather spoil for some favorite charity." See also (1928) 13 CoRN. L. Q. 270.

32. 2 Williston, Contracts (Rev. ed. 1936) \$ 494 and cases cited. 
serves as evidence, making a writing unnecessary, or estops the promisor from setting up the Statute. Early objections that respect for the Statute required that the promisee only be recompensed for his expenditures have not prevailed $_{3}{ }^{33}$ and specific performance is the general remedy. In a promise to give land, possession and improvements not only remove the bar of the Statute, but either serve as consideration or estop the promisor from asserting lack of consideration. ${ }^{34}$ The improvements must be substantial, ${ }^{95}$ and occasionally the value of the expenditures alone has been given. ${ }^{30}$

From this parallel and the fact that courts have talked of fraud and estoppel similarly in both instances it is a reasonable inference that the decisions in the cases of a promise to make a gift of land result from an unwarranted analogy to the cases of promises for an exchange within the Statute. ${ }^{3 i}$ It is urged that justice would require that the promisee be reimbursed and sent on his way, particularly where the expenditures do not approximate the value of the land. ${ }^{38}$ It may well be that a wider recognition of the intermediate remedy of reliance damages would lead to at least that much relief in the cases where the improvements are held insubstantial. But it cannot be said

33. Foster v. Hale, 3 Ves. 696 (1798); Wainwright v. Talcolt, 60 Conn. 43, 22 At1. 484 (1891); Worth v. Worth, 84 Ill. 442 (1877).

34. N'eale v. Neales, 9 Wall. 1 (U. S. 1869); Freeman v. Freeman, 43 N. Y. 34 (1870) ; 1 Willistoa, Coxtracts (Rev. ed. 1936) p. 499. The Massachusctts doctrine is peculiarly strict. Mforse v. Winslow, 254 Mass. 407, 150 X. E. 158 (1926).

Licenses, being inherently revocable, are said not to be made cniorceable by relianse

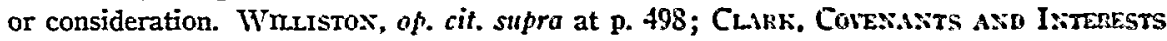
Runatis With the Laxi (1929) 46 et seq.; Shattuck, supra note 9, at 924 el seq. But there is substantial authority contra. Id. at 925, n. 50; Albricht v. Drake Lumber Co., 67 Fla. 310, 65 So. 98 (1914); Beard v. Link, 81 Ind. App. 293, 141 X. E. 792 (1923); Rerick v. Kern, 14 S. \& R. 267 (Pa. 1826).

35. Beall v. Clark, 71 Ga. 818 (1883); Perkins v. Perkins, 181 Mass. 401, 63 N. E. 926 (1902); Griggsby v. Osborn, \&2 Va. 371 (1886); Shattuck, supra note 9, at 221 , n. 44.

36. Usher's Ex'r v. Flood, 83 Ky. 552 (1886) ; of. Mfims v. Lockett, 33 Ga. 9 (1891); Young v. Glendenning, 6 Watts. 509 (Pa. 1837); Shattuch, supra note 9, at 922, n. 45.

37. But there is a closely analogous group of cases where the promisce has moved from a distance in reliance on a promise to give land. Oiten the promise is enfored as a bargain. Often there factually is none, and reliance is the only "consideration." Sce, e.g., Howe v. Watson, 179 Mass. 30,60 N. E. 415 (1901); Brackicnbury v. Hodglin, $116 \mathrm{Me}$ 399, 102 At1. 106 (1917). Greiner v. Greiner, $131 \mathrm{Kan} .760,293$ Pae. 759 (1930) cites Restatearent, Coxtracts (1928) $\$ 90$ as the basis for its decision. Conlra: Kirksey v. Kirksey, 8 Ala. 131 (1845); cf. Chapel v. Chapel, 132 MIinn. 86, 155 X. WY. 1054 (1916). The reliance may be held to involve no damage. Brevator $v$. Creceh, 186 MIo. 558, 85 S. W. 527 (1905); Reed's Heirs v. Vannorsdale, 2 Leigh 569 (V2. 1831). Or reliance may be too little. Dunshee v. Dunshee, 255 Ill. $296,99 \mathrm{~N}$. E. 593 (1912). Another ground for non-enforcement is the lack of intention to be bound. "Assurances of assistance accompanying kind advice are never intended as contracts. And conformance to advice is never intended to stand as legal consideration . . ." Richards' Ex'r $v$. Richards, $46 \mathrm{~Pa} .78,82$ (1863).

38. Shattuck, supra note 9, at 919-924. 
the courts have not had the remedy at hand if they wished to use it..$^{30}$ Moreover it is difficult to see why the promisor who has stood by and seen both the possession and the making of improvements should be let off with less than his word. The feeling that the promisee is getting something for nothing is carried over from the case of a contract to sell, where the promisor receives his bargained-for exchange. In the promise to give he has asked no exchange. In both cases the promisee is given his expectation of the land, unless in the promise to sell the consideration is grossly inadequate ${ }^{40}$ or in the promise to give the reliance too little.11 It seems unnecessary that the substitution of action in reliance for a bargained-for exchange should affect the disposition of the expectation interest.

It may be argued that, by giving the expectation interest, action in reliance becomes an anomalous reason to enforce a promise, ${ }^{42}$ and that it would be as well to enforce promises with no reliance at all. But traditionally, the law has demanded something in the way of a reason for enforcing the promise and an assurance that the promise can be taken to have been intended to be carried out. Only then will the expectations of the promisee be protected. Consideration itself concededly has somewhat of an evidential function. ${ }^{43}$ Definite action in reliance on the promise serves the purpose as well as a bargained-for exchange. ${ }^{44}$ Judicial reasoning in terms of estoppel and fratud - saying the promisee would be defrauded were the promise not enforcedis significant. It has been argued there can be no estoppel by promise because there is no fraud in change of mind, ${ }^{4 \Sigma}$ and that even if there were the promisee

39. See cases cited supra note 36 .

40. 5 Williston, Contracts (Rev. ed. 1936) $\$ 1428$ and authorities cited; REstrateMENT, CONTRACTS (1932) §367 (a).

41. See cases cited supra note 35 .

42. In a moral atmosphere that would hold a bargain the sine qua non of promise enforcement it may seem odd to be compelled to perform a promise for which the promisor was to receive nothing. See Holmes, supra note 3. Further, liability by unbargainedfor detriment is ex post facto, and it can be urged that the promisor cannot predict what his rights and duties will be. But the various legal reasons for enforcing promises are not matters of philosophic truth but to a large extent devices to safeguard against imposition. So it seems unnecessary that a promisor have any more certainty of prediction than that he will be expected to keep his word.

43. See Lord Mansfield in Pillans v. Van Microp, 3 Burr. 1663, 1669 (K. B. 1765); Holmes, The Conmon Law (1881) 259. Compare the fact that possession and improvements will do away with the necessity for a writing in a contract for the sale of land within the Statute of Frauds.

44. As has been seen, there are instances, notably charitable stubscriptions and marriage settlements, where the promise may be enforced without either consideration or action in reliance. But note that these promises are almost invariably in writing.

45. Starry v. Korab, 65 Iowa 267, 21 N. W. 600 (1884) ; Prescott v. Jones, 69 N. H. 305, 41 Atl. 352 (1898); Jordan v. Money, 5 H. L. Cas. 185 (1854); Alderson v. Maddison, 5 Ex. D. 293 (1879-80). But often the promise is such an indefinite expression of intention that reliance is unreasonable. Keating v. Orne, $77 \mathrm{~Pa}$. St. 89 (1874); cf. Marsh v. Bridgeport, 75 Conn. 495, 54 Atl. 196 (1903); Wisconsin \& M. Ry. v. Powers, 191 U. S. 379 (1903) ; Plumer v. Lord, 9 Allen 455 (Mass. 1864); Langdon v. Dowd, 10 Allen 433 (Mass. 1865). 
should nevertheless be limited to reliance damages. Conventional estoppelestoppel in pais-is based on the false statement of an existing fact, and, if it should be beyond the power of the speaker to make his statement true, it may be that damages can only be assessed in terms of reliance. But where the speaker can make the statement true, he has generally been compelled to.45 And in what is called promissory estoppel it is always within the speaker's power to fulfill his words. Because reliance is required to deprive him of the privilege of changing his mind is no reason it need limit the duty. Calling the estoppel one by fraud is the statement of the conclusion that the promisor has come to owe a duty co-extensive with the terms of his promise. ${ }^{.7}$ Such a duty is a contract.

\section{B. Other Promises}

In passing from promises to make a gift the problems involved take on added complexity. There, with the exception of the charitable subscription cases, the promisee is usually a near relative or close friend, and in general the promisor is dead and thus unobjecting when suit is brought. Conceptions of contract are more readily tempered by conceptions of morality and justice. But, where the promises are in general concerned with business of one sort or another, contract conceptions, offer and acceptance as well as consideration, are more likely to prevail, and expediency and business custom are added factors tending to create a different morality. The reasonableness of reliance will thus vary widely according to the situation. But it is necessary to rely upon promises in order that business may be transacted with convenience, and, despite the standardized contract, there are still many such promises which lack conventional consideration. Reliance has therefore played

46. Bold v. Hutchinson, 20 Beav. 250 (1855) ; Dayhood v. Neely, 135 Miss. 14, 99 So. 440 (1924) ; International Products Co. v. Erie R. R., 244 X. Y. 331,155 N. E. 662 (1927) (damages the same whether by reliance or by the statement fulfilled); Fuller, supra note 9, at 406, citing authorities contra. There is a considerable body of decisions holding that where $A$ gives his note or signature to a bank to bolster its assets he must pay after reliance by third parties. See, c.g., Golden v. Cervenko, 278 III. 409, 116 N. E. 273 (1917); Prudential Trust Co. v. Moore, 245 Jiass. 311,139 N. E. 645 (1923); of. Lawrence-Cedarhurst Bank v. Ruth, 162 Misc. 82, 294 X. Y. Supp. 810 (Sup. Ct. 1937), (1938) 48 Y ALE I. J. 326. Although the cases can be analyzed as enforcing promises by third party reliance, it seems more accurate to consider them as cases of estoppl in pais-as representations that the note is a valid asset in the hands of the bank. However, the distinction is purely doctrinal.

47. Compare the opinion that the basis for some contract liability was deccit. See Restatearent, Coxtracts (1928) 245, explanatory note to $\$ 90$; Gt. Brit. Law REx. Couns., loc. cit. supra note 2. See also Finlay v. Swirsky, 103 Conn. 624, 631, 131 Atl. 420, 423 (1925) : "And so it has been said that every sufficient consideration, although not technically an estoppel, contains the substantial elements of an estoppel in pois, for if a man by his promise induces another to change his situatien and is then permitted to deny the validity of the promise, he is thus perpetrating a fraud and injuring another by a false promise. The law will not permit this, but will hold him to the fulfillment of his undertaking." 
its part here also as evidencing the need for a legal duty in the promisor. The expectation of the promisee that the promise may be relied upon is at least indicative that such is the custom and such should be the law.

As would be expected, the promises easiest to enforce by action in reliance are those not involving an affirmative undertaking on the part of the promisor. Promises or conduct implying an assurance not to plead the statute of limitations, ${ }^{48}$ to extend a redemption period, ${ }^{40}$ or not to insist upon part of a contractual right ${ }^{50}$ are made enforceable by the induced inaction of the promisee whether bargained-for or not. An application to have the life of a patent reduced, made under a mistake of law, upon which a third party increased his business, has estopped the patentee from suing the third party. ${ }^{\text {"1 }}$ A promise by a bank to look solely to the maker of a note for payment, wherefore the indorser did not file his claim against the maker ;20 a promise to accept thirty per cent of a debt inducing the debtor not to go into bankruptcy; ${ }^{53}$ a promise not to enforce a dower right in land, wherefore the buyer bought; ${ }^{54}$ and a promise not to foreclose a mortgage, wherefore the mortgagor made improvements, have been enforced.55 But in the famous Petterson v. Pattberg, ${ }^{56}$ a relinquishment of a right was held unenforceable on doctrines of offer and acceptance. In that case the promisee was put in no worse position by reason of his reliance, save for wasted effort, than if the promise had not been made. In the cases listed above the promisee would have been misled to his loss and the status quo would have been un-

48. McLearn v. Hill, 276 Mass. 519, 177 N. E. 617 (1931); Renackowsky v. Board of Comm'rs, 122 Mich. 613, 81 N. WV. 581 (1900); Utica Ins. Co. v. Bloodgood, 4 Wend. 652 (N. Y. 1830). Of course the forbearance of the creditor is often bargained for. But cf. Phillips v. Phillips, 163 Cal. 530, 127 Pac. 346 (1912) where a creditor's pronise not to sue for 10 years estopped the debtor to plead the statute although the debtor had evidently said nothing. Contra: Burnett v. Turner, 105 Ark. 290, 151 S. W. 249 (1912); Shapeley v. Abbott, 42 N. Y. 443 (1870); cf. Langdon v. Doud, 10 Allen 433 (Mass. 1895).

49. Schroeder v. Young, 161 U. S. 334 (1896); Daniel v. Daniel, 190 Ky. 210, 226 S. W. 1070 (1921) ; Dow v. Bradley, 110 Me. 249, 85 Atl. 896 (1913).

50. Little v. Phoenix Ins. Co., 123 Mass. 380 (1877); Underwood Typewriter Co. v. Century Realty Co., 220 MIo. 522, 119 S. W. 400 (1909); Merchant's Nat. Bank v. Voudouris, 248 S. W. 810 (Tex. 1923) ; cf. Imperator Realty Co. v. Tull, 228 N. Y. 447,127 N. E. 263 (1920). Contra: Bragg v. Danielson, 141 Mass. 195, 4 N. E. 622 (1886) ; cf. Marsh v. City of Bridgeport, 75 Conn. 495, 54. Atl. 196 (1903). The parol evidence rule may be insuperable. Insurance Co. v. Mowry, 96 U. S. 544 (1877). But cf. Lechler v. Montana Life Ins. Co., 48 N. D. 644, 186 N. W. 271 (1921) (subsequent agreement).

51. Edison Electric Light Co. v. Buckeye Electric Co., 59 Fed. 691 (C. C. N. D. Ohio 1894).

52. Bulloch v. First Nat. Bank, 196 Iowa 522, 194 N. W. 930 (1923).

53. Melroy v. Kemmerer, 218 Pa. 381, 67 Atl. 699 (1907).

54. Wire v. Wyman, 93 Ind. 392 (1883).

55. Faxton v. Faxon, 28 Mich. 159 (1873); Roe v. Fleming, 32 Okita. 259, 122 Pac. 496 (1912) ; cf. McNeil v. Call, 19 N. H. 403 (1849).

56. 248 N. Y. 86,161 N. E. 428 (1928). 
restorable were the promise not fully enforced. Yet the decision in Petlerson v. Pattberg seems harsh.

The problem becomes more acute when the promise involves affirmative action. It may seem more reasonable to require a quid pro quo before imposing an affirmative duty. Nevertheless the affirmative duty has been imposed in a variety of situations. A promise by a debtor to secure his debt is enforceable because of the creditor's induced forbearance to proceed immediately against him. ${ }^{j \bar{t}}$ The same result has generally been reached where a promise of payment by $A$ has led a creditor not to proceed against his debtor $B:{ }^{: 3}$ The underlying theory in most cases probably is that if the forbearance was not bargained-for it should have been, either because it was a benefit to the promisor or because the promisee should be expected to consider it so. If a tacit understanding is evident, the lack of formal promise or bargain is immaterial, the basic theory being the expectability of fulfillment whether the motions of bargain have been performed or not. And it is a short step from a bargain implicit to a bargain implied, and thence perhaps to the enforcement of promises purely by reliance without implying a bargain..$^{* 0}$

Unilateral Contracts: In what are called offers for a unilateral contract there is much doctrine that would hold there has been no acceptance and no consideration until the requested performance has been completed. ${ }^{69}$ Until then the offeree has been presumed to be free to discontinue and the offeror to revoke his offer. Although the hardship of this is apparent, it has been urged that the offeror is privileged to qualify his offer in any way he pleases, and caveat offeree. From the business point of riew, the better practice has been to allow him to restrict the terms of his offer, yet to hold him to his promise if the accepting performance has been commenced, giving the acceptor a reasonable time to complete. ${ }^{.1}$ It has been stated that the action must be part of the requested performance and not mere preparation. The cases so holding are often those where a request for a counter promise has been found

57. Alliance Bank Ltd. v. Broom, 2 Drew. \& Sm. 289 (Ch. 1864); Hay v. Fortier, $116 \mathrm{Me}$ 455, 102 Atl. 294 (1917), Comment (1918) 27 Yale L. J. 535; Fluclicy v. Anderson, 132 Neb. 664, 273 N. W. 41 (1937) [Restatesie:st, CoNmicrs (1932) $\$ 90$ cited].

58. Bowen r: Tipton, 64 MId. 275, 1 Atl. 861 (1885); Saunders v. Galbraith, 40 Ohio App. 155, 178 N. E. 34 (1931) [RestateveNt, Contricts (1928) $\$ 90$ cited], (1932) 80 U. of PA. L. Rev. 594. Cantra: Manter v. Churchill, 127 Mass. 31 (1879); Strong $\checkmark$. Sheffield, 144 N. Y. 392, 39 N. E. 330 (1895) ; cf. AIcCowen v. MlcCord, 49 G3. App. 353, 175 S. E. 593 (1934).

59. See Wigan v. English \& Scottish Law Life Ins. Ass., [1909] 1 Ch. 291, 298.

60. Campbell Inv. Co. v. Taylor, 246 Ill. App. 433 (1927); Petterson v. Pattberg, 248 N. Y. 86, 161 N. E. 428 (1928); 1 Williston, Contracts (Rev. ed. 1936) \$60.

61. Los Angeles Traction Co. v. Wilshire, 135 Cal. 654, 67 Pac. 1086 (1902); 1 IViritston, Contracts (Rev. ed. 1936) §60A; Restitesrent, Contmcts (1932) §45; Ballantine, Acceptance of Offers for Unilateral Contracts by Parlial Performance of Service Requested (1921) 5 MInx. L. Rev. 94; Corbin, Offer and Acecplance and Some of the Resulting Legal Relations (1917) 26 YALE L. J. 167; sce discussion in Llewellyn, Our Case Law of Contract: Offer and Acceptance II (1939) is YALE L. I. 779. 
or implied. ${ }^{62}$ In fact it is usually difficult to distinguish between preparation and performance.

Exclusive Agencies: The exclusive agency cases are illustrative of this difficulty. The promise may be enforced because the agent has nearly contracted with a buyer or because he has spent time and money seeking one.03 Either could be called part performance or preparation. In the case of an exclusive agency it is true that the promisee could give a consideration to make the promise irrevocable, ${ }^{61}$ but the promisor likewise could phrase his promise so the agent would not be led to rely upon an exclusive agrency. Courts often speak of the agent's performance as implying a counter-promise, but the analysis is belied not only by the fact the agent is probably still not bound, but also by the fact the promise is not enforced if the action taken in reliance is small or incidental. ${ }^{65}$ Any action would presumably serve as well as more to evidence a counter-promise. The form of the promise, followed by the agent's definite and expectable reliance, ground the duty. And if the agent has done enough work to bind the promisor at all, he should be allowed the full benefit of the promise. Although the case might seem one where reliance damages alone could well be given, ${ }^{66}$ and should be where the provable clamages are held insufficient to ground a promissory duty, it is impossible to calculate the value of commissions the agent might have earned elsewhere, and out-of-pocket expenses obviously will not wholly compensate him. Giving the promised commission is therefore the better solution.

- Options: As the exclusive agencies are made capable of enforcement by action in reliance because the terms of the promise make reliance reasonable, it seems the same result must follow in the case of options. Admittedly, neither a general listing of land with a real estate broker nor a statement land is for sale would be made binding by any amount of reliance by the broker-agent or by a prospective purchaser. But when the promise is limited to an exclusive agency or an exclusive option for a given time, the reasonableness and expectability of reliance is the same in either case. Perhaps it is because the

62. See, e.g., Stensgaard v. Smith, 43 Minn. 11, 44 N. W. 669 (1890); Strong v. Sheffield, 144 N. Y. 392, 39 N. E. 330 (1895); White v. Corlies, 46 N. Y. 467 (1871) (reliance very smail). Stensgaard $v$. Sinith would seem to have been overruled by Lapham v. Flint, 86 Minn. 376,90 N. W. 780 (1902).

63. Harris v. McPherson, 97 Conn. 164, 115 Atl. 723 (1921); Braniff v. Baier, 101 Kan. 117, 165 Pac. 816 (1917) ; cf. Bassick Mfg. Co. v. Riley, 9 F. (2d) 138 (E. D. Pa. 1925). Contra: Auerbach v. Internationale Wolfraun Lampen Altien Gesellschaft, 177 Fed. 458 (S. D. N. Y. 1910) ; E. I. DuPont de Nemours \& Co. v. Claiborne-Reno Co., 64 F. (2d) 224 (C. C. A. 8th, 1933).

64. Kelp Ore Remedies Corp. v. Brooten, 129 Ore. 357, 277 Pac. 716 (1929) (\$1 consideration sufficient).

65. Schoenmann v. Whitt, 136 Wis. 332,117 N. W. 851 (1908); cf. Curtiss Candy Co. v. Silberman, 45 F. (2d) 451 (C. C. A. 6th, 1930).

66. In Schwarz v. Lou-Ala Inv. Co., 23 Ala. App. 498, 127 So. 786 (1930), reliance damages alone seem to be given. And see Kolb v. Bennett Land Co., 74 Miss. 567, 569, 21 So. 233, 234 (1897). 
action in reliance of the exclusive agent is apt to be like performance of a unilateral contract, while reliance upon a gratuitous option is not, that gratuitous options have not been so frequently enforced. But substantial reliance should be sufficient to make șuch promises binding. ${ }^{6 t}$

Promises of an option for a time certain are in reality most conducive to reliance. They have been upheld where the consideration was obviously nominal, ${ }^{68}$ and while it is here again true that the promisee could have his option by thus paying consideration, yet the promisor could as easily refrain from phrasing his promise so it leads to reliance. Between the two, payment of consideration seems merely a form for the wary, and the form of the promise the substance of the matter. The reliance of the promisee should generally either cause the promise to be irrevocable or be of no effect at all, depending upon the terms of the promise and the extent of the reliance. There might, of course, be cases where only reliance damages would achieve justice between the parties, but any reliance sufficient to make a suit for reparation worth the bringing should be sufficient to enforce the option itself. Either relief should be altogether denied under a principle of $d c$ minimis, or if the promise is to carry a duty, the tendency should be to extend the duty to the terms of the promise as a conventional contractual obligation rather than to the makeshift reparatory duty. The expectation of the promisee is as worthy of protection after reliance as after a nominal consideration given. In either case the expectation is created and limited by the promise. It is no more just, upon the promisor's non-performance, to restore to the promisee the amount of his reliance than it would be to return to him the consideratiun he gave. To say that reliance cannot invoke the promissory duty because mere reliance is not consideration is pure question-begging, especially in view of the behavior of courts in assimilating the two. ${ }^{69}$ Indeed, courts have only recently distinguished between them. Furthermore, in both the option and exclusive agency cases the promisor either gets his stipulated return or loses nothing

67. Wilson v. Spry, 145 Ark 21, 223 S. W. $36+$ (1920); Spitzli v. Guth, 112 Mfisc. 630, 183 N. Y. Supp. 743 (Sup. Ct. 1920). Contra: Comstock Bros. v. Torth, 88 Mfiss. 754,41 So. 374 (1906) (\$5,000 reliance, option revocable); Corbett v. Cronthite, 239 Ill. 9 (1909) (\$25 reliance); Texas Co. v. Dunn, 219 S. W. 300 (Tex. Cir. App. 1920) (same). In Ganss v. Guffey Petroleum Co., 125 App. Div. 760, 110 \$. Y. Supp. 176 (1st Dep't 1908) reliance of $\$ 150$ upon an option to purchase a ship for $\$ 85,000$ was held in a 3 to 2 decision not to make the option binding. But the parties had agreed to a higher price, reserving to the buyer the right to sue for the difference. See Gr. Brit. Luw Rx: Comar., supra note 2 , at 23 , urging that an option for a definite time be irrevoable.

68. Smith v. Bangham, 156 Cal. 359, 104 Pac. 689 (1909) (\$1.00 consideration makes an option to buy land worth $\$ 17,000$ binding).

69. There may be very important questions yet to be answered as to whether a promise should always be enforced in full and as to when the giving of reliance damages would better serve society. But assuming the problem, it in no wise follows that the answer to the very practical question of how much the plaintiff should recorer is to be found in the distinction in legal doctrine between a bargained-for exclunge and reliance. Doetrines developed to determine whether liability exists at all should not control the cstent of the liability. 
but other opportunities to sell, which loss is presumably offset by the increased opportunity to sell to or through the exclusive promisee.

Gratuitous Undertakings: The cases of gratuitous undertakings go deepest into the history of the common law, being part of the ancient law of bailments and to some extent the basis of assumpsit. ${ }^{70}$ The amorphous character of their beginning and the conflicting claims of tort and contract categories have led to considerable opinion that the liability created is of a type all its own. ${ }^{71}$ One principle is fairly certain: a gratuitous undertaking entered upon and improperly performed will result in liability. ${ }^{72}$ Whether the duty is truly of tort or of contract or truly neither is perhaps of only academic importance. The duty is the same whether it be grounded in the promise or imposed by law, and so the measure of damages. When the facts are such that it is impossible to say the promisor has commenced the undertaking, the various bases for the imposition of liability become more important. Either the tort duty must be extended to deprive the term non-feasance of its traditional immunizing force, or the contractual duty must be extended by reason of reliance. It is true that courts have been readier to impose liability where there has been something entrusted to the promisor - chattel ${ }^{73}$ or note ${ }^{74}$. and the duty could be fictionally conceived of as an extension of the bailec's duty to use due care. But liability has been imposed without the something given, ${ }^{\mathrm{T5}}$ and insofar as the liability springs from the fact of a promise, the

70. Ames, loc. cit. supra note 2; 1 Clark, Cases on Pleading and Procedure (1930) 275-286; Holdres, op. cit. supra note 2, at 275 ct seq.; 1 Wildiston, Contracts (Rev. ed. 1936) $\$ 138$.

71. Beale, Gratuitous Undertakings (1891) 5 HARv. L. Rev. 222; Arterburn, Liulil ity for Breach of Gratnitous Promises (1927) 22 IL.. L. REv. 161. The latter atuthor says liability is, or should be, sti generis; but his argument that liability cannot properly be of tort because the duty is affirmative seems wrong. The duty may be as easily thought of as negative, i.e., a duty not to promise unless prepared to carry out the promise-practically speaking the same duty that attaches as soon as the undertaking is entered upon.

72. Coggs v. Bernard, 1 Salk. 26 (K. B. 1703) ; Ralli Bros. v. Walford Lines, Ltd., 13 Lloyd's List L. R. 223 (H. L. 1922) (promise to insure) ; Barile v. Wright, 256 N. Y. 1, 175 N. E. 351 (1931) (same).

73. Schroeder v. Mauzy, 16 Cal. App. 443, 118 Pac. 459 (1911); Siegel v. Spear, 234 N. Y. 479,138 N. E. 414 (1923) (promise to insure).

74. Mayhew v. Glazier, 68 Colo. 350, 189 Pac. 843 (1920) (promise to insure); Moore v. Gholson, 34 Miss. 372 (1857) (promise to collect claims) ; Herzig v. Herzig, 67 Misc. 250, 122 N. Y. Supp. 440 (Sup. Ct. 1910) (promise to collect a note); if. Stone v. Demarest, 95 Misc. 543, 159 N. Y. Supp. 800 (1st Dep't 1916).

75. Lusk-Harbison-Jones, Inc. v. Universal Credit Co., 164 Miss. 693, 145 So. 623 (1933) [promise to insure, Restatement, Contracts (1932) $\$ 90$ cited] ; Kirby v. Brown, 229 App. Div. 155, 241 N. Y. Supp. 255 (1st Dep't 1930) (promise to bid on property); Watkins v. James, 48 N. C. 195 (1855) (promise to procure a draft) ; cf. Johnson v. Longley, 142 Ga. 814, 83 S. E. 952 (1914). Contra: Elsee v. Gatward, 5 T. R. 143 (K. B. 1793) (promise to repair a house); Spillane v. Yarmalowicz, 252 Mass. 168, 147 N. E. 571 (1925) ; Tomko v. Sharp, 87 N. J. Law 385, 94 Atl. 793 (1915) (promise to return car from garage); Thorne v. Deas, 4 Johns. 84 (N. Y. 1809) (promise to insure); Comfort v. McCorkle, 149 Misc. 826, 268 N. Y. Supp. 192 (Sup. Ct. 1933) (promise to 
duty would seem to fall more properly under contract. In Coggs a. Bernardis the defendant undertook to carry wine and spilled it. His negligence produced the damage regardless of promise; the duty breached was always with him, namely, not to break the cask. Where one has promised to insure for another, and does so, but improperly, he is liable upon the destruction of the property not because he has damaged the property nor because he has increased the risk of damage, but because he has not performed his promise, which promise caused the risk to go unprovided for. He had no duty to insure until he promised. The duty there would seem to be contractual, and the line generally drawn dividing improperly insuring from not insuring at all ${ }^{77}$ must surely be the result of mistaken technicality.

The tendency to carry over into the contract category the distinction between non-action and action improperly executed is of course attributable to the indeterminate origin of the gratuitous undertaking cases. For as far as the ultimate basis of liability is concerned, there may be no real distinction between such a case as Seigel $v$. Spcar, ${ }^{78}$ where liability was imposed for the non-performance of a promise to insure, and the group of cases including MacPherson v. Buick ${ }^{79}$ and Glanzer v. Shepard. ${ }^{80}$ In the latter line of decisions the duty so to conduct oneself as not to harm another was extended so as to require a manufacturer not to increase the risk of physical damage by sending out a defective car, and to require a public weigher not to increase the risk of pecuniary loss by issuing a false statement certifying the weight of beans. These duties were imposed, despite the doctrine of privity of contract, by conceiving the defective car to be like harmful conduct, if it cause damage, and the false statement to be like a defective car-a dangerous thing to let loose in the world. As one may in general rely upon the proper conduct of one's neighbor so may one in general rely upon the soundness of a car and the integrity of a statement. In Scigel $v$. Spear the contractual duty was imposed. There enforced was a promise to insure upon which another relied, in that he did not himself insure. It is true that the plaintiff in Glanzer $v$. Shepard was damaged because he relied not on a promise but on a statement, wherefore he did not weigh the beans himself; yet the identity of consequence should point out that the difference in the legal doctrine applied is merely a matter of convenience in achieving a result. Conduct, car, statement, and promise may bring liability if they cause another harm. Basically each line

file a claim). The Restatement of Agency would impose liability. Rest.ıtevesr, Agencr (1933) § 378; and see RestatesreNt, Torts (1934) \$325.

76. 1 Salk. 26 (K. B. 1703).

77. Wilkinson v. Coverdale, 1 Esp. 75 (K. B. 1793) (negligent insuring, liability); Barile v. Wright, 256 N. Y. 1, 175 N. E. 351 (1931) (same); Spillane v. Yarmelowicz, 252 Mass. 168, 147 N. E. 571 (1925) (failure to have plaintiff's name inserted in rolicy;, no liability); Thorne v. Deas, 4 Johns. 84 (N. Y. 1809 ) (iailure to insure, no liability).

78. 234 N. Y. 479,138 N. E. 414 (1923).

79. 217 N. Y. 382,111 N. E. 1050 (1916).

80. 233 N. Y. 236,135 N. E. 275 (1922). 
of cases is authority for the other. Yet the situations are not wholly the same, and the very presence of a promise seems to turn the legal rationale to contract. Certainly the promise is one "the performance of which the law in some way recognizes as a duty," 81 and the presence of such a promise makes the case one of contract rather than of tort. There is therefore no reason for distinguishing between the negligent performance of the promise and its nonperformance, a dichotomy responsible for an unfortunate and confusing body of tort law. The damage is precisely the same, of course, in either event, and recovery the same upon any theory.

A further analogy can be drawn between the two classes of cases. In Glanzer $v$. Shepard the duty of the weigher to speak with care if he spoke at all was imposed because the defendant knew the plaintiff would rely on his statement. In Ultranares Corporation v. Touche, Niven \& Company, ${ }^{82}$ a similar liability was denied, whether rightly or wrongly, because it was thought the defendant could not have foreseen the reliance of any particular person, and further because the burden of responsibility upon him would be too great. A sufficient closeness of relationship-determinableness of who will rely-m to make reliance reasonable and expectable, is also required in the gratuitous undertaking cases before any duty will be imposed, ${ }^{83}$ And although there are other factors affecting the reasonableness of reliance, the burden of the promise to the promisor, should it be enforced, frequently seems determinative. Thus in Brawn v. Lyford $d^{84}$ the defendant's promise to send an insurance policy to the company to be assigned was not enforced, although defendant was bailee of the policy and the building subsequently burned. Liability would have made him the insurer. In Carr $v$. Maine Central Railroad ${ }^{85}$ the defendant owed plaintiff a rebate which could not be paid without the assent of the.Interstate Commerce Commission. The plaintiff delivered the necessiary papers to defendant, which undertook to send them to the Commission and did not. Liability was imposed, but the defendant had only to pay what it owed the plaintiff anyway. Although liability has been imposed where Braz'n v. Lyford denied it, ${ }^{86}$ and the authority of Thorne v. Deas ${ }^{87}$ has been ques-

81. Restatement, Contracts (1932) $\$ 1$.

82. 255 N. Y. 170,174 N. E. 441 (1931), modified in, State St. Trust Co. v. Ernst, 278 N. Y. 104,15 N. E. (2d) 416 (1938), reargument denied, 278 N. Y. 234, 16 N. F. (2d) 851 (1938). See also Moch Co., Inc. v. Rensselaer Water Co., 247 N. X. 160, 159 N. E. 896 (1928).

83. At least such a state of facts has always existed in the cases. The requirement of a certain privity, however, seems inseparable from considerations of burden, should liability be imposed. Cf. Winterbottom v. Wright, 10 M. \& W. 109 (E:. 1842).

: 84. 103 Me. 362, 69 Atl. 544 (1907).

85. 78 N. H. 502, 102 Atl. 532 (1917).

86. Schroeder v. Mauzy, 16 Cal. App. 443, 118 Pac. 459 (1911) ; Maylew v. Gilazicr, 68 Colo. 350, 189 Pac. 843 (1920) ; Lusk-Harbison-Jones, Inc. v. Universal Credit Co., 164 Miss. 693, 145 So. 623 (1933); Siegel v. Spear, 234 N. Y. 479, 138 N. E. 414 (1923).

87. 4 Johns. 84 (N. Y. 1809) -the leading American case refusing liability for the non-performance of a gratuitous agency. 
tioned, ${ }^{88}$ the treatment of the gratuitous undertaking cases shows that emphasis is laid in some cases not so much on the reliance as on the prumise. The reliance is always the same, namely non-action, but the extent of loss increases directly with the extent of the promise. So the greater the burden of the promise to the promisor the less reasonable the reliance upon another to perform it gratuitously, ${ }^{89}$ and the promisee may retain a duty to look out for himself. .0

Conclusion: It is certain that consideration in the sense of a bargained-for exchange has not been found satisfactory as an c.rclusie'c device for enforeing promises. ${ }^{91}$ As the only other means to create the promised duty, action in reliance may seem to have unduly $e x$ post facto operation. Yet it is doubtful that the problematical surprise of a defendant bound by action in reliance is a matter for sympathy. As has been seen, the requisite amount of reliance has varied in different situations. Perhaps the requirement of "sulustantial" reliance may give the matter a more delictual aspect than is desirable, but it may be that a sort of burden of proof has been put upon the promisee, rather than that the enforceability of the promise has been made to depend upon the greatness of the injustice of non-enforcement. In the marriage settlenent and charitable subscription cases can be found examples of promises including duties for no perceptible doctrinal reason, but mercly beeause the courts think enforcement is proper. And the employee benefit promises, stipulated to be non-binding, are made enforceable by the employee continuing work as usual, ${ }^{92}$ although in any other situation there would probably le no "consid-

88. Siegel v. Spear, 234 N. Y. 479, 484, 138 N. E 414, 416 (1923).

89. Nor is this principle limited to the gratuitous undertaking cases. Compare Charles E. Quincy \& Co. Arbitrage Corp. v. Cities Service Co, 156 Mise. \$3, 282 X. Y. Supp. 294 (Sup. Ct. 1935) with Simmons v. Randforce Anusement Corp., 162 Mise. 491, 293 N. Y. Supp. 745 (MIun. Ct. 1937) and De La Bere v. Pearson, Ltd. [1907] 1 K. B. $4 \$ 3$ (C. A.).

90. It may be worth noting that looked at in another way, in that the reliance cunsists of doing nothing, the gratuitous undertaking cases are further authority for the proposition that mere expectation, although it must be reasonable, is sufficient to create the duty to satisfy the expectation in him who aroused it.

91. See Dunlop Pneumatic Tyre Co., Ltd. v. Selfridge, [1915] A. C. 847, 855; Pou:rn, Ax Introdoction to the Philosophy of Law (1922) 271 al seg.; Ballantine, Is the Doctrine of Considcration Senselcss and Illogical? (1913) 11 Mfıcr. L. Rev. 423; V'right, Ought the Doctrine of Consideration to be Abolished from the Common Late? (1936) 49 HARV. L. REv. 1225. Lord Wright points out the distinetion between the civil law, taking contractual intent as its criterion of promise enforcement, and the common law, requiring something outside of intent. It is hoped this comment also shows that the latter criterion is a backhanded way of discovering the former. The doctrine of consideration is discredited precisely insofar as it fails to do so. Hence the importance of preserving reliance as a further device to enforce the whole promise, or not, as justice requires.

92. Tilbert v. Eagle Lock Co., 116 Conn, 357, 165 Atl. 205 (1933); Psutha v. MLichigan Alkali Co., 274 Mfich. 318, 264 N. W. 385 (1936), (1936) 36 CoL. L. REx. 996; of. Zwolanek v. Baker Mffg. Co., 150 Wis. 517, 137 X. W. 769 (1912). Contra: Areyerson v. New Idea Hosiery Co., 217 Ala. 153, 115 So. 94 (1927); d. AfcGovern v. City of New York, 234 N. Y. 377, 138 N. E. 26 (1923); Shear Co. v. Harrington, 265 S. W. 
eration" and the force of the promisee's expectation would go for nothing. In general something tangible must take place because of the promise, such as marriage or continued employment, ${ }^{93}$ and in the vast majority of the cases the action in reliance has made the full promise enforceable. Authority holding that the reliance, rather than the promise, should limit the duty is negligible.

Reliance may be no better an exclusive test than consideration, but if consideration is to be definitively limited to a bargained-for exchange, there are occasions where action in reliance must be invoked as an indispensable supplement. Where it is felt that the parties, had they intended to contract, would have contracted by offer and acceptance, the reliance doctrine is less frequently applied. $^{94}$ If reliance and contractual intent are both clear, there is no reason why the absence of a bargain need compel a court either to refuse relief or to limit the relief to reliance damages. Courts should have all possible tools with which to enforce a promise, and not be bound to one. They have been fully capable of distinguishing those promises which were not intended to create a legal obligation $;^{95}$ they should be permitted to enforce those which were. It is not that in a citable case they have not reached the desired result. but that the very vigor of contractual doctrines has been too restrictive upoin equally citable occasion. ${ }^{96}$ As far as action in reliance is concerned, courts look on the one hand to the promisee to see if there is sufficient reason to enforce the repudiated promise, and on the other to the promise to see if the action of the promisee was such as would be expectable. Their purpose, as in all contracts, is to protect reasonable expectations which society takes an interest in fulfilling.

554 (Tex. 1924). Compare also Kiser v. Amalgamated Clothing Workers of America, 194 S. E. 727 (Va. 1938), where a union's promise to keep up plaintiff's salary should she be discharged from work because of joining the union was enforced.

93. Shear Co. v. Harrington, 266 S. W. 554 (Tex. 1924).

94. Compare the great weight of authority enforcing promises to make a gift by reason of reliance with the fewer cases enforcing promises by reliance in the business setting.

95. See, e.g., Weeks v. Tybald, Noy 11 (K. B. 1605) ; Wisconsin \& M. Ry. v. Powers, 191 U. S. 379 (1903); Higgins v. Lessig, 49 Ill. App. 459 (1893); Unangst v. Unangst, 213 Iowa 1064, 240 N. W. 618 (1932); Walker v. Walker, 175 Mass. 349, 56 N. E. 601 (1900); Keller v. Holderman, 11 Mich. 248 (1863); cf. Grimes v. Haker, 132 Neb. 898, 273 N. W. 789 (1937), aff'd, 133 Neb. 517, 275 N. W. 860 (1937). Compare further In re Greene, 45 F. (2d) 428 (S. D. N. Y. 1930). See also Wright, supra note 91, at 1227 et seq.

96. See, e.g., Alderson v. Maddison, 5 Ex. D. 293 (1879-80); Bragg v. Danielsón, 141 Mass. 195, 4 N. E. 622 (1886) ; Comstock Bros. v. North, 88 Miss. 754, 41 So. 374 (1906) ; Tomko v. Sharp, 87 N. J. Law 385, 94 Atl. 793 (1915) ; Comfort v. McCorkle, 149 Misc. 826, 268 N. Y. Supp. 192 (Sup. Ct. 1933). 